\title{
A Study on Shaanxi Colleges and Universities of Music Serving the Belt and Road Initiative
}

\author{
Du Lei \\ Department of Vocality, Xi'an Conservatory of Music, Shaanxi, China, 710061
}

Keywords: The Belt and Road; Colleges and Universities of Music; Research; Significance

Abstract: President Xi Jinping attended the opening ceremony of the Belt and Road Forum for International Cooperation and made a keynote speech titled Work Together to Build the Silk Road Economic Belt and the 21st Century Maritime Silk Road. President Xi proposed the thought of "Five Roads", among which the road of innovation and the road connecting different civilizations indicate the directions for the research; the road connecting different civilizations advocates cultural cooperation, promotes educational cooperation and gives play to the functions of the think tank; and the road of prosperity calls for the release of development potential and the cultivation of new forms of industry. Colleges and universities of music have made a series of efforts to respond to "the Belt and Road" Initiative. Taking the talent cultivation and social service of colleges and universities as the entry point, the research in this paper focuses on the measures of Shaanxi colleges and universities of music in serving "the Belt and Road" Initiative and the way of better integrating the functions of talent cultivation, scientific research and social service to achieve an organic industry-university-research combination, based on the special rules of colleges and universities of music.

As the starting point of "the Belt and Road" (the B\&R), Shaanxi possesses large amounts of higher educational and scientific research resources, with various kinds of colleges and universities in this city. As the B\&R Initiative is proposed, the political, economic and cultural communication between China and $B \& R$ countries has become increasingly frequent. The $B \& R$ is a road of win-win cooperation, which can improve mutual development, realize common prosperity and promote the joint and integration of the development strategies of $B \& R$ countries. Under the great pattern and general trend of the $B \& R$, the introduction of investment strategy along with the integration and innovation of economy, culture and society has become the primary task. This has opened up a new road for the rise and prosperity of Chinese culture, thus helping the Chinese culture to realize self-improvement and go to the world.

These resources play an important and crucial role for Shaanxi Province to respond to the B\&R Initiative, facilitate its economic and cultural construction and realize strong economic and cultural province, hence creating a bridgehead for the $B \& R$. At present, in order to respond to the $B \& R$ Initiative, Shaanxi Province has established the Universities Alliance of Silk Road and made a great effort in constructing the technical education center, in which various kinds of colleges and universities can bring the educational advantages of their own disciplines into full play. At the same time, the leading role of technical innovation has been developed, the breakthrough of key and core 
technologies has been accelerated and the international exchange and cooperation in industry-university-research combination and talent cultivation has been strengthened. Moreover, the road for jointly cultivating creative talents can be explored, more talents can be attracted to Shaanxi and universities can also be made to settle in Shaanxi by establishing bilateral and multilateral international cooperation mechanism, deepening the international training and education cooperation, speeding up the construction of Western China Science \& Technology Innovation Harbor Wisdom Uni-Town as well as Silk Road Economic Zone Education and Cultural Exchange Research Center and Human Resources Service Industrial Park and giving play to the role of the Universities Alliance of Silk Road.

\section{The Educational Features of Colleges and Universities of Music}

Colleges and universities have three functions, which are talent cultivation, scientific research and social service. One of the main parts of universities' social service function is serving the national major policies. Among China's colleges and universities, those of music are in a special position and have received the widespread attention of the society in recent years. Therefore, how to give the features of colleges and universities of music into full play to provide better social service is a very realistic problem.

The education in colleges and universities of music is unique, the value orientation of which takes the market demand as the target. Firstly, the educational objective of colleges and universities of music is closely related to the social development. To cater to the need of the era, colleges and universities of music have cultivated a large number of inclusive and comprehensive inter-disciplinary talents who learn a wide range of contents, reserve multi-disciplinary basic knowledge and take a certain specialty as their major development direction so as to smoothly adapt to the changes in social development. Secondly, the talents cultivated by colleges and universities of music own both the personality of the career and the spirit of the time. Apart from learning on campus, they contact with the society and understand the social development trend, so that they can fully reveal their music characteristics based on their personality and specialty.

The present age is an age in which the culture is exchanged, shared and integrated. In the premise of community interest, China is showing its culture $\&$ art as well as cultural features on the international stage. The function of colleges and universities of music in talent cultivation can be seen more clearly when it comes to responding to the urban musical cultural construction in the B\&R Initiative. The colleges and universities of music not only provide outstanding comprehensive musical talents as well as intellectual support for the society and actively intensify the urban and enterprise cooperation, but also participate in the creation of urban theme music and popular music. Through the implementation of culture plus strategy, the art of music is promoted and the urban cultural atmosphere is enhanced with good culture, traditional factors and the view of Chinese studies. At the same time, the music industry is developed, the industrial state of music culture is expanded and the connotation of cultural products is improved, thereby accelerating the development of other industries through the guidance of music.

One of the features of China's colleges and universities of music is its immediate effect. The difference between colleges and universities of music and other kinds of universities lies in that the former takes social art group as the main occupational direction of talents. Specifically, colleges and universities of music pay attention to developing students' social practice ability when they are learning on campus, so that their social service effect can be tested as long as they get out of school. In this way, the "preparation time" before students get a job will be greatly shortened, and the professional and technical talents can serve the society timely. Therefore, colleges and universities of music constantly understand what kinds of talents are needed by the society and systematically 
make their students participate in social practice and connect closely with the social development trend from learning by doing. Accordingly, the school curriculum contents have to closely be related to practice and the boring and rigid traditional teaching model also has to be broken.

Therefore, in combination with the music education in Shaanxi colleges and universities, the service function for major national strategies can be realized through many ways. At the same time, the service channel will be expanded, the service range will be increased and the service strength will be enhanced. Besides, the positive effects of teaching and research on social service will also be explored from the three aspects of teaching, scientific research and social service, with the emphasis put on social service.

\section{The Research Status of Domestic and Overseas Colleges and Universities Serving "the Belt and Road"}

Currently, the international talents under the background of the $B \& R$ have been widely investigated, whereas few studies have been conducted on the measures of domestic and overseas colleges and universities serving the B\&R. In terms of how universities should serve national strategies, many colleges and universities have taken corresponding measures. For example, Xi'an Conservatory of Music have established the "Belt and Road" Music Institute for Advanced Study, signed cooperation intention letter with the Working Committee of the Belt and Road of CASME and carried out music activities with the theme of the B\&R actively.

Following problems exist in current relevant researches: firstly, too many studies focus on the cultivation of national talents or the opportunities and challenges faced by the development of colleges and universities. Meanwhile, these studies are at a relatively low research level and lack of corresponding theoretical research foundation; secondly, colleges and universities put more emphasis on the research of the economic effect of the B\&R, while there are few cultural studies on this Initiative; thirdly, the colleges and universities in Shaanxi study less on the B\&R Initiative, and most existing researches derive from the colleges in eastern region; and fourthly, there are too many case studies, most of which take a certain university as a case to investigate the influence of the $\mathrm{B} \& \mathrm{R}$ on college education, and hence there is a lack of comparative study and theoretical and empirical analysis.

\section{The Theoretical and Practical Significance of Colleges and Universities of Music Serving "the Belt and Road"}

The great era needs great wisdom, and the B\&R Initiative that carries the Chinese wisdom will certainly arouse the strength of China and promote the world economic development. In the meantime, the strong resonance of the $B \& R$ countries will also be aroused, because it revives people's historical memory and combines history and reality, culture and business as well as path and dream, hence forming a cohesion that transcends time and space. Therefore, the B\&R is not only the reflection of the world cooperation and development, but also the carrier of the oriental wisdom.

The professional talents provided by colleges and universities of music for the society have also made great contribution to the development of the B\&R. Colleges and universities are the first resource for the output of talents to the society. Science and technology constitute the primary productive force, innovation is the first motivation, and culture is the first soft power. With their own outstanding advantages, various disciplines gather a large number of professional talents together, collect all kinds of information and present remarkable social practice effect with concentrated innovation elements and frequent international communication. Thus, great and special contribution is made to serving the economic socio-economic development and powerful 
intellectual and talent support is offered to the society. In this paper, based on existing research, an attempt is made to study how the music education in colleges and universities should respond to the national B\&R Initiative and how the social service function of universities should be put into good use in a better way. At the same time, an investigation is also carried out on how to better serve the national B\&R Initiative through teaching, scientific research and art practice, by which the social function service of colleges and universities of music can be strengthened and the effective combination as well as the mutual coordination and growth of teaching, scientific research and social service can be promoted.

An important historical mission of higher education is to take part in the socio-economic development and enhance the social service function. How to fulfill this mission needs constant practice and exploration. A distinguishing feature of colleges and universities of music is that they serve the socio-economic development via their own advantages in discipline, profession, science and technology, information and culture. Colleges and universities of music have played an important role in the socio-economic growth. For instance, they have cultivated large quantities of excellent comprehensive talents and thrown themselves into high and new cultural and technical enterprise, not only contributing greatly to the growth of economy and the increase of economic creativity and competitiveness, but also expanding the survival and development space of themselves. Practice has proved that colleges and universities of music can find their own existence value and obtain richer development resources by establishing good interaction mechanism with the socio-economic growth and tightly adhering to the socio-economic development demand only. Colleges and universities of music and economic growth should support and help each other, which is determined by the law of economic development. To be specific, when the economy is developed, more financial support will be provided for the development of colleges and universities of music, while when the colleges and universities of music are developed, they will have more powerful strength to support economic growth. New requirements are raised by the socio-economic growth to colleges and universities. During the process of serving the economic society, colleges and universities should constantly improve their school conditions, optimize their school environment and expanded the talent team. Also, they should enhance their preponderant disciplines, strengthen their scientific research innovation ability, improve the talent cultivation quality and increase their comprehensive strength and competitiveness. Only in this way can they significantly enhance their capability of serving the socio-economic development.

The special base for the culture of music and dance is built to show the scenic spots and historical sites in Shaanxi via music culture performance and to connect the ancient culture of music and dance with the modern popular music in the $21^{\text {st }}$ Century. Furthermore, the society is guided to actively develop multicultural international exchange to spread the culture of music and dance and to create the spreading and communication platform of the B\&R music and dance.

Nowadays, the social service function advocated in institutions of higher learning not only requires that colleges and universities should devote themselves to scientific research and teaching or cultivate the students' social value of "immediate service" and put it into practice. Also, it does not mean that previous scientific research education will be replaced by the social service project. Instead, it refers to integrating the idea of social service into teaching and research, so that the social service function of universities' teaching and scientific research can be given into full play.

The significance of this study lies in that it is the first time to study how colleges and universities of music serve the national B\&R Initiative, which can improve the dimension of universities' social service function and help to respond to the strategy of Shaanxi strong cultural province. As the starting point of the B\&R, Shaanxi has rich educational resources and good geographic advantage, and it can serve the development of other regions through educational resources integration. In addition, Shaanxi is also one of the cities in China that have a lot of colleges and universities. The 
great number of higher education institutions and scientific research institutions along with the high-quality teachers and reserve of excellent talents can lay a solid foundation for talents exchange. The teaching and academic communication among the colleges and universities of music can not only make the national students master the professional skills better, but also make the professional feature of universities clearer. In this way, more overseas students will be attracted to China and Shaanxi, and meanwhile the Chinese students can also "go out" to strengthen their mutual cultural and academic exchange. More importantly, Shaanxi is one of the cradles of the long-standing Chinese civilization and it has profound historical culture. Currently, there are 9 world-class tangible cultural heritages and various scenic spots and historical sites in Shaanxi, attracting large amounts of foreign friends. Therefore, the economic growth in Shaanxi can be promoted via tourism culture, and the economic development vitality of this city can also be boosted through the combination of tourist industry and the cultural and art industry as well as the spread of Shaanxi culture to the $\mathrm{B} \& \mathrm{R}$ countries via the Internet, forum, exhibition and performance, art show, and so on.

As the highest education institution in Shaanxi's colleges and universities of music, Xi'an Conservatory of Music grasps the development trend of contemporary Chinese culture, carries out firm cultural confidence and develops socialist literature and art based on the strategic significance of cultural development. As a result, rich food for thought is provided for people, people's demand for high art like the music culture is met and the prosperity and development of socialist literature and art career with Chinese characteristics as well as the construction of strong cultural province is actively facilitated. In this paper, the important role of Shaanxi colleges and universities of music, represented by the Xi' an Conservatory of Music, in the B\&R Initiative is studied and the current shortcomings of them are found out in combination with related situations of other Shaanxi universities. Meanwhile, the condition of how several other colleges and universities of music in China serve the national strategy is investigated, in order to provide effective strategic advice and policy suggestion for colleges and universities of music.

\section{References}

[1] Actively Participating in "the Belt and Road", the Internal and External Economic Construction of Shaanxi Province, Shaanxi Daily, Wang Ting, 2017.7.11

[2] Copland. What to Listen for in Music [M]. Beijing: People's Music Publishing House, 1984.

[3] Pei Long. Research on the Management Mechanism of Public Music Education in Regular Institutions of Higher Learning [J]. A View of Labor Unions · Theoretical Research, 2009 (1).

[4] Bu Genhai. The Power of Music [M]. Shanghai: Shanghai Literature \& Art Publishing House, 1991.2.

[5] Shen Bo. Several Reflections on Strengthening the Professional Construction of Higher Vocational Education [J]. Journal of Shaanxi Institute of Junior Managerial Personnel, 2003.

[6] Yang Mingang. Realistic Thinking on the Sustainable Development of China's Higher Vocational Colleges [J]. Chinese Vocational and Technical Education, 2008 (9).

[7] Dong Yuepeng. Thinking on the Higher Vocational Music Education [J]. Contemporary Education Window, 2010 (4).

[8] Liao Honggang. Musicology in Colleges and Universities (Musical Education Major, Curriculum Setting Study) [D]. Tibet University, 2017.

[9] Research Team of "the Belt and Road". The Establishment of Five Centers for "the Belt and Road" in Shaanxi [J]. Shanghai Securities News, 2015.8 